\title{
Marine Biodiversity \\ Xenophyophores (Protista, Foraminifera) from the Clarion-Clipperton Fracture Zone with description of three new species \\ --Manuscript Draft--
}

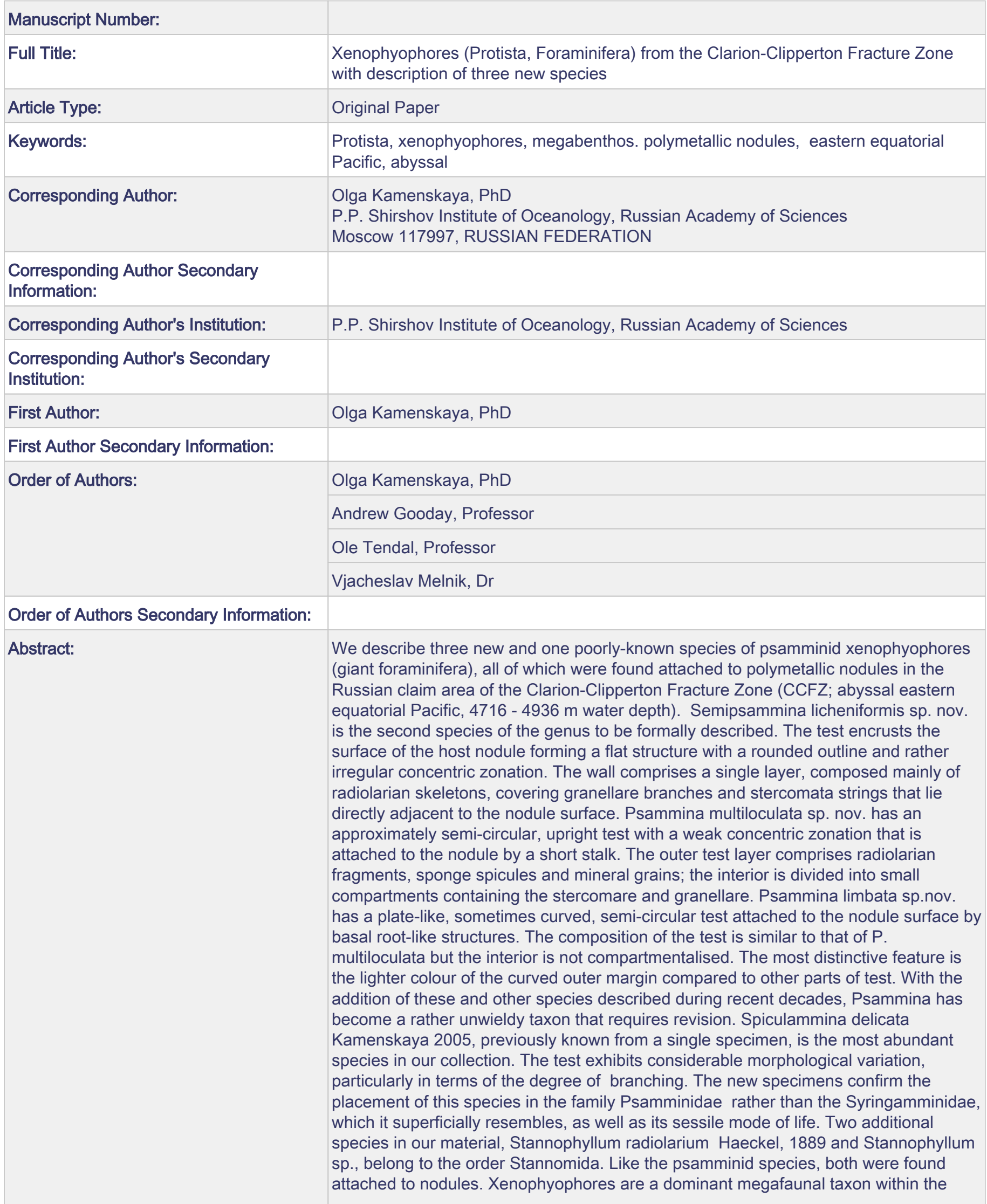


CCFZ. Although limited, our new material suggests that this region hosts many novel taxa.

Suggested Reviewers: 


\title{
Xenophyophores (Protista, Foraminifera) from the Clarion-Clipperton Fracture Zone with description of three new species
}

\author{
O.E.Kamenskaya ${ }^{1}$, A.J.Gooday ${ }^{2}$, O.S.Tendal ${ }^{3}$, V.F.Melnik ${ }^{4}$ \\ 1 - P.P.Shirshov Institute of Oceanology RAS, 117997 Moscow, Nakhimovsky prosp. 36, \\ Russia; e-mail: olkamenskaya@yandex.ru \\ 2 - National Oceanography Centre, University of Southampton, Waterfront Campus, European \\ Way, Southampton SO 14 3ZH, United Kingdom; e-mail: ang@noc.ac.uk \\ 3 - State Natural History Museum of Denmark (Zoological Museum), University of \\ Copenhagen, Universitetsparken 15, 2100 Copenhagen O, Denmark; e-mail: \\ ostendal@snm.ku.dk \\ 4- Yuzhmorgeologiya State Scientific Centre, 353461, Gelendzhik, Krymskaya St., 20, \\ Russia; e-mail:melnikvf@ymg.ru
}
Abstract We describe three new and one poorly-known species of psamminid xenophyophores (giant foraminifera), all of which were found attached to polymetallic nodules in the Russian claim area of the Clarion-Clipperton Fracture Zone (CCFZ; abyssal eastern equatorial Pacific, 4716 - 4936 m water depth). Semipsammina licheniformis sp. nov. is the second species of the genus to be formally described. The test encrusts the surface of the host nodule forming a flat structure with a rounded outline and rather irregular concentric zonation. The wall comprises a single layer, composed mainly of radiolarian skeletons, covering granellare branches and stercomata strings that lie directly adjacent to the nodule surface. Psammina multiloculata sp. nov. has an approximately semi-circular, upright test with a weak concentric zonation that is attached to the nodule by a short stalk. The outer test layer comprises radiolarian fragments, sponge spicules and mineral grains; the interior is divided into small compartments containing the stercomare and granellare. Psammina limbata sp.nov. has a plate-like, sometimes curved, semi-circular test attached to the nodule surface by basal root-like structures. The composition of the test is similar to that of $P$. multiloculata but the interior is not compartmentalised. The most distinctive feature is the 
34 lighter colour of the curved outer margin compared to other parts of test. With the addition of these and other species described during recent decades, Psammina has become a rather unwieldy taxon that requires revision. Spiculammina delicata Kamenskaya 2005, previously known from a single specimen, is the most abundant species in our collection. The test exhibits considerable morphological variation, particularly in terms of the degree of branching. The new specimens confirm the placement of this species in the family Psamminidae rather than the Syringamminidae, which it superficially resembles, as well as its sessile mode of life. Two additional species in our material, Stannophyllum radiolarium Haeckel, 1889 and Stannophyllum sp., belong to the order Stannomida. Like the psamminid species, both were found attached to nodules. Xenophyophores are a dominant megafaunal taxon within the CCFZ. Although limited, our new material suggests that this region hosts many novel taxa.

Key words. Protista, xenophyophores, megabenthos. polymetallic nodules, eastern equatorial Pacific, abyssal

\section{Introduction}

Xenophyophores are giant marine, agglutinated deep-sea protists (Tendal, 1972) that are confined to regions below about $500 \mathrm{~m}$ water depth. Since the first species were described in the 1880s, (Brady, 1883; Haeckel, 1889), they have been variously classified as foraminifera, sponges or as a distinct protistan group (Tendal, 1972). However, recent molecular analyses place at least some species within the radiation of basal monothalamous foraminifera ('monothalamids') (Pawlowski et al., 2003, 2013; Lecroq et al., 2009; Gooday et al., 2011). Xenophyophores are particularly abundant in areas where the food flux is enhanced, for example, on seamounts and ridges, in submarine canyons and under productive surface waters, including the eastern equatorial Pacific (Tendal, 1972; Tendal and Lewis 1978; Levin and Thomas 1988; Levin, 1994).

Interest in xenophyophores has been heightened recently by their abundance in the Clarion-Clipperton Fracture Zone (CCFZ), a large tract of the equatorial Pacific where polymetallic nodules ('manganese nodules') are particularly abundant. The International Seabed Authority (ISA) has awarded contracts to countries and companies to exploit nodules in designated claim areas within the CCFZ. Our previous investigations have revealed that 
xenophyophores are a key megafaunal group within the Russian claim area in the central part of the Clarion-Clipperton nodule field (Kamenskaya et al., 2013). They were seen in $70 \%$ of sea-floor photographs and were found in $30 \%$ of box-cores samples collected during a 2007 cruise of Research Vessel Yuzhmorgeologia. Their average density was 1600 specimens per hectare, with a maximal value of 120,000 specimens per hectare $\left(=12\right.$ specimens per $\left.\mathrm{m}^{2}\right)$; the next most common group, the Actiniaria, did not exceed a density of 170 specimens per hectare. According to earlier studies on eastern equatorial Pacific seamounts, the abundance and species diversity of macro- and meiobenthos is elevated in sediments beneath and close to xenophyophore tests compared to sediments where no xenophyophores are present (Levin et al.,1986; Levin and Thomas, 1988). Diverse assemblages of metazoans and foraminifera also inhabit the cavities and interstices of xenophyophore tests (Levin and Thomas, 1988; Levin 1994; Hughes and Gooday, 2001). Therefore, in the areas where these giant protists dominate, they probably play an important role in the structuring of benthic communities. Their study is especially important in the light of likely future polymetallic nodule mining within the CCFZ.

Following Tendal (1972), we recognize two main xenophyophore groups: stannomids (order Stannomida of Tendal, 1972) and psamminids (order Psamminida of Tendal 1972). Both groups are present in the central part of the Clarion-Clipperton nodule field, either attached to the nodules (species of the genera Psammina, Semipsammina, Stannophyllum and Spiculammina) or living on soft sediment between the nodules (species of Psammina and Reticulammina). About $60 \%$ of these xenophyophores have a leaf-like test shape and probably belong to genera Psammina and Stannophyllum. The tree-like species Spiculammina delicata was seen in $10 \%$ of bottom photographs. Here, we analyze the taxonomic composition of the xenophyophore fauna attached to nodules from the central part of the CCFZ and describe three new species in the genera Psammina and Semipsammina. In the absence of material suitable for molecular analyses, our descriptions are based on morphological characters.

\section{Material and methods}

The material was obtained using a box corer (cross-sectional area $0,25 \mathrm{~cm}^{2}$ ) from different parts of the Russian claim area of the Clarion-Clipperton nodule field $\left(13-14^{\circ} \mathrm{N}, 130-135^{\circ} \mathrm{W}\right)$ during four cruises of the Research Vessel Yuzhmorgeologia in 2003, 2006, 2009 and 2010 (Table 1). Nodules with xenophyophores were collected from the surface of the box-core 
samples. Xenophyophores were carefully removed from the nodules and preserved in $70 \%$ ethanol. For SEM study fragments of specimens were mounted on aluminium stubs and coated with Au. Analysis of chemical constituents (Ba) was performed with an energydispersive X-ray spectrographic analyzer (EDS) connected to a scanning electron microscope (CamScan and Zeiss EV050). The holotypes are deposited in the collection of the Zoological Museum of the Moscow State University.

Semipsammina licheniformis sp. nov. Kamenskaya. Gooday, Tendal Fig. 1 a-f

Semipsammina sp. Kamenskaya, Melnik, Gooday 2013: 391-392, Fig. 6d

Material examined. The holotype was from St. 60-1 of R/V Yuzhmorgeologia cruise 4-06, $13.26^{\circ} \mathrm{N}, 134.41^{\circ} \mathrm{W}$; depth $4777 \mathrm{~m}$. The holotype is deposited under registration number F16

Diagnosis. Encrusting test covering part of nodule surface. Outline more or less rounded with irregular margin that includes occasional elongate extensions. Test surface with concentric pattern of linear, step-like features. Maximum test dimension up to $\sim 6 \mathrm{~cm}$; thickness decreasing from $\sim 3 \mathrm{~mm}$ in central part to $\sim 1 \mathrm{~mm}$ near margin. Agglutinated test wall composed of radiolarian skeletons with occasional diatom frustules and sponge spicule fragments; test wall covers interior space that contains strings of granellare and stercomare 
Description of holotype. The test of the single available specimen is light greyish in colour and forms a flattened structure that encrusts the surface of a polymetallic nodule. It has an approximately circular outline, measuring $6.1 \times 4.9 \mathrm{~cm}$, and covers about half of the nodule surface, following the curved contours of the substrate (Fig. 1 a). The thickness in the central part is about $3 \mathrm{~mm}$, decreasing to $1 \mathrm{~mm}$ near the margins. The surface of the test has distinct, concentric step-like features, most clearly developed in the central part and probably reflecting episodic growth. The margin of the test is irregularly rounded and often displays small lobate features. Several long narrow extensions of the margin, having the form of a flattened tube, are also developed; they are up to $1 \mathrm{~cm}$ long, sometimes branching, and consist of either naked granellare or granellare covered with xenophyae.

The test forms an upper layer that covers the granellare and stercomare. The xenophyae (agglutinated particles) comprise a jumble of complete and fragmentary radiolarian skeletons, with scattered micronodules and occasional diatom frustules and small fragments of sponge spicules, creating a fairly rough surface texture (Figs. 1 b, c). There are some internal xenophyae. The granellare and stercomare lie directly adjacent to the nodule surface; some parts are also attached to the inner surface of the test wall, as seen when parts of the test wall are detached (Fig. 1 d). The granellare are light in colour and form strands, 50 to $100 \mu \mathrm{m}$ in diameter, which branch but do not anastomose (Fig.1 d). The strands contain numerous granellae, 3-4 $\mu \mathrm{m}$ in length with the ovate shape typical of xenophyophore barite crystals (Fig.1 e). The stercomare masses form branching structures, ranging from less than $50 \mu \mathrm{m}$ to more than $100 \mu \mathrm{m}$ in diameter, containing stercomata with a diameter $<10 \mu \mathrm{m}$ (Fig. 1).

Etymology. From Latin and English "lichen"

Distribution. Currently know only from one site in the Russian license area of the ClarionClipperton Fracture Zone, Eastern Pacific, depth 4777 m (Table 1).

Remarks. The only previously described species of the genus, Semipsammina fixa Tendal 1975, is known from two specimens and some fragments attached to turtle grass rhizomes from the Puerto Rico Trench (depth 6000-5890 m). The plate-like body of S. fixa is irregularly rounded in outline, up to $5.5 \mathrm{~mm}$ in diameter and $\sim 0.5 \mathrm{~mm}$ in thickness. The xenophyae comprise sponge spicules and mineral particles. Our new species differs from $S$. fixa mainly in the much larger size of the test and the nature of the xenophyae. There also appear to be differences in the shape of stercomare system. 
170

Genus Psammina Haeckel, 1889

180 Remarks. The genus was established by Haeckel (1889) based on three species, Psammina 181 nummulina, P. globigerina and P. plankina. According to the diagnosis given in Tendal 182 (1972), the main features of Psammina are 1) a discoidal test with large pores around the margin, 2) firmly cemented xenophyae forming hard, upper and lower plates, 3) internal xenophyae forming pillar-like structures between the two plates, and 4) granellare branches and stercomare strings strongly developed between the pillars. Gooday and Tendal (1988) added three further species, $P$. delicata, $P$. fusca, and $P$. sabulosa, These conform more or less to the diagnosis of Tendal (1972), although none has a clearly discoidal shape, marginal pores are evident only in $P$. sabulosa, and $P$. fusca lacks internal pillars as well as pores. Tendal (1994) described P. zonaria, a bathyal species from the western Pacific with an elongate test that widens towards its distal end and is subdivided internally into transverse compartments. Finally, Kamenskaya and Saidova (1998) redescribed Psammina planata (Saidova) 1970, a hadal species from the western Pacific that was originally placed in the genus Astrorhizinella.

Here, we assign two additional species to the genus Psammina. They also deviate from the original concept of Psammina in certain respects. In the future it may be necessary to divide this now rather heterogenous group of species into two or more distinct genera.

\section{Psammina multiloculata sp. nov. Kamenskaya, Gooday, Tendal}

Figs. 2, 3

Material examined. The holotype was from St. 28 of R/V Yuzhmorgeologia cruise 4-06, $13.28^{0} \mathrm{~N}, 134.41^{0} \mathrm{~W}$; depth $4843 \mathrm{~m}$. The holotype is deposited under registration number F17. Other material: one specimen from St. 8726, one specimen from St. 8655, one specimen from St. 204. . 
Diagnosis. More or less semicircular, plate-like test, sometimes with additional side plate, attached to hard substrate by short, wide, basal stalk. Outer layer of test consisting of small fragments of radiolarian skeletons, sponge spicules and mineral grains. Surface is granular at base and with weakly developed concentric zonation most evident close to margin. Inner space divided into numerous compartments containing strings of granellare and stercomare .

Description. Holotype (Fig. 2 a-c): The test is flat, plate-like, and was attached to a nodule by its longest side without the development of a stalk. The dimension of the intact specimen is $24 \times 18 \mathrm{~mm}$ but the test was broken into several fragments during preparation. One of these fragments includes the base of a side plate (Fig. 2 c). The surface of the test is noticeably granular at the base and shows concentric zones, which are most clearly visible near the outer margin (Fig. 2 a, b). The outer layer of the test is composed of small fragments of radiolarian skeletons, sponge spicules and mineral grains (external xenophyae). The test interior is divided into compartments by internal xenophyae; along the abraided margin the compartments appear as open spaces filled with dark stercomata (Fig. 2 c).

Specimen from St. 204 (Figs 2 d, 3 a-g): The specimen broke into fragments during preparation (Fig.2d). The undamaged test formed a more or less flat structure with a relatively smooth, semi-circular outline, $31 \mathrm{~mm}$ wide and $24 \mathrm{~mm}$ high, originally attached to the host nodule by a short flattened stalk about $9 \mathrm{~mm}$ wide. The thickness varied from $3 \mathrm{~mm}$ at the basal part of the test to $2 \mathrm{~mm}$ close to margins. As in the holotype, the test surface is granular near the base, becoming more smooth towards the margin, and the xenophyae are small fragments of radiolarian skeletons, sponge spicules and mineral grains (Fig. 3 a, b). The inner space of the test is divided into numerous small compartments, each measuring about $600 \times 400 \mu \mathrm{m}$ (Fig. 3 c). These spaces are occupied by granellare and stercomare. The granellare branches are up to 50-100 $\mu \mathrm{m}$ wide and extend through several compartments (Fig. $3 \mathrm{c}, \mathrm{f}$ ). They contain numerous barite crystals (granellae), no more than $2 \mu \mathrm{m}$ in length. (Fig. $3 \mathrm{~g}, \mathrm{~h}$ ). The stercomare masses may be oval in shape and occupy one chamber (Fig.3-d), or arranged in strings and extend between several compartments The oval masses are typically 400-500 $\mu \mathrm{m}$ long and $\sim 200 \mu \mathrm{m}$ wide (Figs.3 c-d). They consist of stercomata with maximum dimensions of $\sim 10-15 \mu \mathrm{m}$.

Other material (Fig 2 e-f): Two more or less intact tests have differing morphologies. The specimen from St. 8655 was originally attached to a nodule. It measures 23 by $13 \mathrm{~mm}$ and consists of three well-developed plates, the angles between them varying from $\sim 90^{\circ}$ to $\sim 170^{\circ}$ 
(Fig. $2 \mathrm{f}$ ). The test surface exhibits a clear concentric zonation and the internal compartments are clearly visible in places through the test wall. The specimen from St. 8726 is smaller, measuring 15 by $11 \mathrm{~mm}$ (Fig. $2 \mathrm{~g})$. The test is fan-like with a short $(\sim 2 \mathrm{~mm})$, wide $(\sim 5 \mathrm{~mm})$ stalk that was originally attached to the surface of a nodule. Concentric zones and internal compartments are visible close to the margin (Fig. $2 \mathrm{~g}, \mathrm{~h}$ )..

Etymology: From Latin "loculata"-divided into small volumes.

246 Distribution: Currently know from four sites in the Russian license area of the Clarion-

247 Clipperton Fracture Zone, Eastern Pacific, depth 4841-4936 m (Table 1).

249 Remarks. Psammina multiloculata differs from other species of the genus in the presence of 250 an elaborate system of small internal compartments. In Psammina zonaria, the test interior is also partitioned into compartments, but these spaces are relatively large and are delimited by transverse bars that occupy the entire width of the test, rather than the tiny cell-like spaces that characterise the new species. In both of these species, the internal structure of the test probably represents an elaboration of the pillars present in species such as $P$. nummulina, $P$. globigerina, and P. plankina.

The basically plate-like test of $P$. multiloculata shows some variability, particularly regarding the degree of development of side plates. The shape is somewhat reminiscent of the foraminiferal genus Jullienella, particularly J. foetida Schlumberger, 1890 and J. zealandica Hayward and Gordon, 1984, in which the test interior is partly subdivided by parallel ridges. However, these are not sufficiently developed to create internal compartments (Buchanan 1960; Nørvang 1961; Hayward and Gordon 1984). Moreover, Jullienella foetida and J. zealandica are not xenophyophores. lacking the typical granellare and stercomare systems, and are confined to sublittoral to upper bathyal depths.

Psammina limbata sp.nov. Kamenskaya, Gooday, Tendal

(Fig.4 a-i)

Psammina sp. Kamenskaya, Melnik, Gooday 2013: 391-392, Fig. 6 b 
Material examined. The holotype was from St. 25 of R/V Yuzhmorgeologia cruise 4-06, $13.28^{0} \mathrm{~N}, 134.45^{\circ} \mathrm{W}$; depth $4724 \mathrm{~m}$. The holotype is deposited under registration number F18.

Etymology. From Latin "limbata"- bordered.

Diagnosis. Flattened, plate-like semi-circular test attached to nodule surface by basal stalk and root-like structures. Outer layer of test composed of firmly cemented fragments of radiolarian skeletons, mineral grains and sponge spicule fragments with weakly developed concentric zonation. Curved outer margin distinctly lighter than other parts of test. Interior friable with strings of granellare and masses of stercomare interwoven with looselyagglutinated spicule fragments; stercomare absent from outer margin. Weakly-developed concentric ridges on inner surface of outer test layers.

Description of holotype. The single collected specimen has a curved, approximately semicircular, plate-like test that was attached to the surface of a nodule by a basal stalk and several long, branched, root-like structures (Fig.4 a, b). It is $\sim 40 \mathrm{~mm}$ wide, $\sim 31 \mathrm{~mm}$ high and $\sim 1 \mathrm{~mm}$ thick. The external xenophyae that form the outer test layer comprise firmly cemented fragments of radiolarian skeletons, small mineral grains and small fragments of sponge spicules (Fig. 4 c). A weakly-developed concentric zonation on the surface of the test presumably reflects episodic growth (Fig. 4 b). A narrow zone around the outer margin comprises only transparent sponge spicule fragments and appears lighter than other parts of the test. Small concentric ridges are developed on the inner surface of the outer test layers (Fig. 4 g), but they do not partition the interior space into compartments. (Fig. 4 h). The interior of the test has a friable consistency and contains larger, loosely organized spicule fragments between which are situated granellare branches, 50-100 $\mu \mathrm{m}$ diameter and masses of stercomare, up to $300 \times 600 \mu \mathrm{m}$ in size (Fig. 4 d). The absence of the dark stercomare from the marginal zone of the test is responsible for its lighter colour (Fig. 4 i). Stercomata range in size from 7 to $20 \mu \mathrm{m}$ (Fig. $4 \mathrm{e}$ ) and the granellae crystals are typically $3 \mu \mathrm{m}$ long (Fig. 4 f).

Etymology. From Latin "limbata"- bordered.

Distribution. Currently know from one site in the Russian license area of the ClarionClipperton Fracture Zone, Eastern Pacific, depth 4724 m (Table 1). 
Remarks. Psammina limbata sp. nov. resembles $P$. multiloculata in the general shape and composition of the test but is not divided into compartments internally, and it has basal root-

like structures that are not present in $P$. multiloculata. The new species resembles $P$. zonaria in the zonation of outer and inner surfaces of the outer test layers, but this zonation does not affect the test interior. The two species also have different test shapes as well as different kinds of xenophyae, namely planktonic foraminiferal shells in $P$. zonaria and siliceous particles in P. limbata.

Material examined: A total of 19 specimens collected during R/V Yuzhmorgeologia cruise 4-06, Stns 25, 34, 39, 43, 49, 52, 85, 94, 95, 118, 119, 122, 133, 150, 151, 159, 164, 166, 167.

Spiculammina delicata Kamenskaya 2005: 23-27, Fig. 1-2

Spiculammina delicata Kamenskaya, Melnik, Gooday 2013: 391- 393, Fig. 6 c

Remarks. Spiculammina.delicata was described by Kamenskaya (2005) based on a single specimen from the central part of the Clarion-Clipperton Fracture Zone $\left(11.52^{0} \mathrm{~N}, 136.06^{0}\right.$ W). Our new material demonstrates the wide distribution of this species within the Russian CCFZ claim area (Table 1). The test varies from several $\mathrm{mm}$ to $5-6 \mathrm{~cm}$ in size and exhibits considerable morphological variation (Fig. 5). Some specimens have a relatively simple tubular form (Fig. $5 \mathrm{~d}$ ) but in most cases the test is tree-like with a basal trunk giving rise to variable numbers of branches that range from long and relatively slender to short and relatively wide. The test is composed almost exclusively of sponge spicule fragments (Figs 6 a-b). Although in some respects it resembles members of the family Syringamminidae (e.g. the genus Aschemonella), Kamenskaya (2005) assigned Spiculammina to the family Psamminidae Haeckel, 1889, based on the presence of sparse xenophyae in the lumen of the tubular test. This placement is supported by examination of the new material, which has 
revealed that the test interior is occupied by numerous internal xenophyae, creating a rigid framework (Fig. 6c). Kamenskaya (2005) suspected that the original specimen, which was fragmented, had been attached to a hard substrate. The new specimens were all growing on polymetallic nodules, confirming the sessile nature of this species.

Spiculammina delicata is easily recognisable in bottom photographs. It was visible in $10 \%$ of the images from the Russian claim area and was collected in many box corer samples (Kamenskaya et al. 2013).

Distribution. In the present study, this species was found at 19 sites in the Russian license area of the Clarion-Clipperton Fracture Zone, Eastern Pacific, depth range 4716-4824 m (Table 1). It was previously known from a single specimen obtained at $11.52^{0} \mathrm{~N}, 136.06^{0} \mathrm{~W}$, 5400 m depth (Kamenskaya 2005).

\section{Stannomid group of species:}

Stannophyllum radiolarium Haeckel, 1889

Fig. 7

Stannophyllum radiolarium Haeckel 1889: 65, pl. I, 2A-C; 9, 53, 61, 66, 68, 70

Stannophyllum radiolarium Schulze 1907a: 36, 41, 42, 49, 50, 52, 53, 54

Stannophyllum radiolarium Schulze 1907b: 160, 162

Stannophyllum radiolarium Laubenfels 1948: 185

Stannophyllum radiolarium Tendal 1972: 13, 15, 44, 45, 54-55, 57, 61, 62, 69, 70, 74, 76, 77, 81, 85, 90, pl. 10F;

Stannophyllum radiolarium Tendal 1973: 26, 28-29

Stannophyllum radiolarium Tendal 1994: 91

Stannophyllum radiolarium Kamenskaya, Melnik, Gooday 2013:392, Fig.6a

Material examined. R/V Yuzhmorgeologia cruise 4-08, St.8639, depth 4750 m (specimen 1); R/V Yuzhmorgeologia cruise 4-06, St. 31, depth 4785 m (specimen 2).

Remarks. Both specimens were originally attached to nodules. Specimen 1 from St. 8639 (Fig. 7 a) has a fan-like test, measuring $22 \times 15 \mathrm{~mm}$, with long and thin tubular processes developed at the base. Specimen 2 from St. 31 (Fig.7 b) has a more elongate, drop-like test 
measuring $32 \times 25 \mathrm{~mm}$. Both have a concentric surface zonation, more pronounced in the case of specimen 1 . The colour is brownish and the consistency is soft. The xenophyae are radiolarian tests (Fig. 7 c). The linellae have a diameter of 1-2 $\mu \mathrm{m}$ and do not anastomose (Fig. $7 \mathrm{~d}$, e). The granellare branches are up to $40 \mu \mathrm{m}$ in diameter and the granellae crystals 1-3 $\mu \mathrm{m}$ long. The stercomare are sparsely developed but are sometimes visible as oval masses up to $200 \mu \mathrm{m}$ in length (Fig. $7 \mathrm{~d}$ ).

The features of these two tests are generally consistent with the description of Stannophyllum radiolarium given by Tendal (1972), which was based on a re-examination of the original Challenger material supplemented by two additional specimens collected during the Galathea Expedition and a Vityaz cruise. However, our specimens (particularly \#1) have a clearly developed surface zonation, a feature not evident in the material examined by Tendal (1972). The Challenger and Galathea specimens were also whitish in colour compared to the brownish appearance of our material, although the Vityaz specimen is described as 'yellow-brown'.

Distribution. Northern, eastern, western and central areas of the Pacific Ocean. Depth 3570$5515 \mathrm{~m}$. In the present study it was recorded at two sites in the Russian license area of the Clarion-Clipperton Fracture Zone, Eastern Pacific, depth 4750-4785 m (Table 1).

\section{Stannophyllum sp.}

Fig. 8

Material examined: Single specimen from R/V Yuzhmorgeologia cruise 18-01, St. 197, depth $4845 \mathrm{~m}$.

Description._The single specimen, originally attached to a nodule, was approximately semicircular in shape, resembling bracket fungus and measured approximately 6 by $3 \mathrm{~cm}$ (Fig. 8 a). The width was about $1 \mathrm{~mm}$ near the outer margin, increasing towards the base. Unfortunately, the test was damaged during collection and lost much of its original morphology when placed in a Petri dish (Fig. 8 b). The colour is brownish and the consistency is flexible. The xenophyae consists largely of complete and fragmentary radiolarian skeletons (Fig. 8 c). The test interior is penetrated by numerous dichotomously branching granellare strands (Fig. $8 \mathrm{~d}$, e), about $20 \mu \mathrm{m}$ in diameter and full of granellae 
crystals about $2 \mu \mathrm{m}$ in length (Fig. $8 \mathrm{f}$, g). Stercomata are quite small (about $5 \mu \mathrm{m}$ ) and organized in oval masses of stercomare covered with organic sheath (Fig. 8 h). Linellae are simple, not anastomosed, $2 \mu \mathrm{m}$ in diameter and form a distinct layer.

Remarks._Our specimen shares some characters with other Stannophyllum species (Tendal, 1972), although it differs in certain respects from all of them. It resembles $S$. zonarium in the type of xenophyae, but lacks the surface zonation of the test typical of this species. The test is soft and flexible as in S. mollum, but the linellae are simple rather than anastomosing. It has the same type of xenophyae (radiolarians) as $S$. radiolarium, but differs from this species in possessing a distinct layer of linellae. The closest match to a known species appears to be with $S$. granularium. The shape and consistence of the test are similar, but in contrast to $S$. granularium, the xenophyae consist almost entirely of radiolarians rather than a mixture of mineral grains and sponge spicules, with a varying proportion of radiolarians (Tendal, 1972).

Distribution. Recorded at one site in the Russian license area of the Clarion-Clipperton Fracture Zone, Eastern Pacific, depth 4845 m (Table 1).

\section{Concluding remarks}

Our relatively small collection of xenophyophores, obtained at depths between 4716 and $4936 \mathrm{~m}$ in the central part of the CCFZ $\left(13-14^{\circ} \mathrm{N}, 130-135^{\circ} \mathrm{W}\right)$, reveals the occurrence of at least six species, three new and one poorly-known species belonging to the order Psamminida and two species belonging to the order Stannomida. All of the specimens were found attached to polymetallic nodules. Previous studies have demonstrated that some xenophyophores are sessile on hard substrates, including rocks and plant material (Pearcey, 1914; Tendal 1975; Levin and Thomas 1988), as well as on and in soft sediments. Mullineaux (1987) reported the genera Semipsammina, Stannoma, Stannophyllum and Syringammina living on nodules from the central $\left(30^{\circ} \mathrm{N}, 157^{\circ} \mathrm{W}\right)$ and equatorial $\left(5^{\circ} \mathrm{N}, 125^{\circ} \mathrm{W}\right)$ North Pacific. Similarly, Veillette et al. (2007) found two xenophyophore-like organisms, one a fan-shaped morphotype and the other lacking agglutinated particles, on nodules from the western $\left(9^{\circ} \mathrm{N}\right.$, $\left.150^{\circ} \mathrm{W}\right)$ and more central $\left(14^{\circ} \mathrm{N}, 130^{\circ} \mathrm{W}\right)$ parts of the CCFZ. Our new material confirms that where nodules are present, they represent an important habitat for these large testate protists, 
which constitute a major element of the megafauna in the CCFZ. We anticipate that additional undescribed species will be discovered in this part of the Pacific Ocean.

Acknowledgments. The study of xenophyophores is supported : OEK by Russian Foundation for Basic Research (RFBR) grant 12-05-33049 and partly by the European Union Seventh Framework Programme (FP7/207-20130 under the MIDAS project, grant agreement $n^{0}$ 603418; VFM by RFBR grant 12-04-01253a; AJG conducts similar work in the CCZ through a commercial arrangement with Seabed Resources Development Ltd.

\section{References}

Brady HB (1883) Syringammina, a new type of arenaceous Rhizopoda, Proc. R. Soc. Lond. 35: $155-161$

Buchanan JB (1960) On Jullienella and Schizammina, two genera of arenaceous foraminifera from the tropical Atlantic, with a description of a new species. J. Linn. Soc. London. Zool. 44: $270-277$

Gooday AJ, Aranda da Silva A, Pawlowski J (2011) Xenophyophores (Rhizaria, Foraminifera) from the Nazaré Canyon (Portuguese margin, NE Atlantic). Deep-Sea Res II 58: $2401-2419$

Gooday AJ, Tendal OS (1988) New xenophyophores (Protista) from the bathyal and abyssal north-east Atlantic Ocean. J. Nat. Hist. 22: 413-434

Haeckel E (1889) Report on the deep-sea Keratosa collected by H.M.S. Challenger during the years 1873-76. Report of the Scientific Results of the Voyage of H.M.S. Challenger during the years 1873-76, Zoology 82:2

Hayward BW, Gordon DP (1984) A new species of the agglutinating foraminifer Julienella (Schizamminidae) from New Zealand. J. Foram, Res. 14: 111-114 
Hughes JA, Gooday AJ (2001) Association between living benthic foraminifera and dead tests of Syringammina fragilissima (Xenophyophorea) in the Darvin Mounds region (NE Atlantic). Deep-Sea Res I 51:1741-1758

Kamenskaya OE (2005) Spiculammina delicata gen. et sp. n., a new xenophyophore from the eastern Pacific (Psamminidae). Invertebr. Zool. 2, 1: 23-27

Kamenskaya, OE, Saidova KhM (1998) Redescription of Psammina planata (Saidova, 1970), a hadal xenophyophore from the Kurile-Kamchatka Trench. In: A.P. Kuznetsov and O.N. Zezina (eds.) Benthos of the High Latitude Regions. Moscow.:137

Kamenskaya OE, Melnik VF, Gooday AJ (2013) Giant protists (xenophyophores and komokiaceans) from the Clarion-Clipperton ferromanganese nodule field (Eastern Pacific). Biology Bulletin Reviews 3, 5: 388-398

Laubenfels MV (1948) The order Keratosa of the phylum Porifera - a monographic study. - Occ. Pap. Allan Hancock Fdn. 3: 1-217.

Lecroq B, Gooday AJ, Tsuchiya M, Pawlowski J (2009) A new genus of xenophyophores (Foraminifera) from the Japan Trench: morphological description, molecular phylogeny and elemental analysis. J. Linn. Soc. London. Zool. 156: 455-464.

Levin LA (1994) Paleoecology and ecology of xenophyophores. Palaios. 5: 32-41.

493 Levin LA, Thomas CL (1988) The ecology of the xenophyophores (Protista) on eastern 494 Pacific seamounts. Deep-Sea Res 35, 12: 2003-2027.

496 Levin LA, DeMaster DJ, McCann LD, Thomas CL (1986) Effects of giant protozoans (class: 497 Xenophyophorea) on deep seamount benthos, Mar. Ecol. Prog. Ser. 29: 99-104

499 Mullineaux LS (1987) Organisms living on manganese nodules and crusts: Distribution and 500 abundance at three North Pacific sites. Deep-Sea Res 34: 165-184 
502 Nørvang A (1961) Schizamminidae, a new family of foraminifera. Atlantide Report 6: 169-

1 503

3 504

505 506 10

201, Pls I - IX

Pawlowski J, Holzmann M, Fahrni J, Richardson SL (2003) Small subunit ribosomal DNA suggest that xenophyophorean Syringammina corbicula is a foraminiferan. J. Eukaryotic Microbiol. 50: 483-487

Pawlowski J, Holzmann M, Tyszka J (2013) New supraordinal classification of Foraminifera: Molecules meet morphology. Marine Micropaleontology 100: 1-10

512 Pearcey FG (1914) Foraminifera of the Scottish Antarctic Expedition. . Transactions of the 513 Royal Society of Edinburgh 49: 991 - 1044.

Saidova KhM (1970) Benthic foraminifers in the Kurile-Kamhatka Region based on the data of the $39^{\text {th }}$ cruise of the R/V Vityaz. Trudy Instituta Okeanologii 86: 134-161

529 Tendal OS (1975) A new xenophyophore, living on solid substratum, and its significance.

530 Deep-Sea Res 22: 45-48.

532 Tendal OS (1973) Xenophyophoria (Protozoa, Rhizopoda) from the collections of the R/V

533 “Vitiaz". Zoologichesky Zhurnal 52: 25-30 
535 Tendal OS (1994) Protozoa Xenophyophorea Granuloreticulosa: Psammina zonaria sp.nov.

1 2536

3 537 538

7539 940 10 11 541 544 from the Wester Pacific and some aspects of the growth of xenophyophores. In: A. Crosnier (ed.). Resultats des Campagnes MUSORSTOM. Vol. 12. Mém. Mus. Nat. Hist. 161: 49-54

Tendal OS (1996) Synoptic checklist and bibliography of the Xenophyophorea (Protista), with a zoogeographical survey of the group. Galathea Report 17: 79-101

542 Tendal OS, Lewis KB (1978) New Zealand xenophyophores: upper bathyal distribution, 543 photographs of growth position, and a new species. N.Z. J. Mar. Freshw. Res. 12: 197-203

Veillette J, Sarrazin J, Gooday AJ, Galéron J, Caprais J-C, Vangriesheim A, Juniper SK (2007). Ferromanganese nodule fauna in the equatorial north Pacific ocean: species richness, 547 faunal cover and spatial distribution. Deep-Sea Research I 54: 1912-1935. 
569

1

2570

3

571

572

573

9574

10

Figure captions

Fig. 1. Semipsammina licheniformis sp. nov., Stn.60-1, cruise 4-06, holotype, registration number F-16; a, b, d, light micrographs; c, e, f, scanning electron micrographs.

a- Intact specimen on the surface of the host nodule

b- Fragment of the surface of the test

c- Surface of test showing xenophyae (mainly radiolarian skeletons)

d- Underside of outer test layer showing granellare branches and dark masses of stercomare

e- Granella (barite crystal) on the surface of a granellare branch

f- Strings of stercomare composed of stercomes

Scale bars: a- 1 cm; b- 1 mm; c- $100 \mu \mathrm{m}$, d- 1 mm; e- $10 \mu \mathrm{m}$; f- $30 \mu \mathrm{m}$

Fig. 2. Psammina multiloculata sp.nov.; light micrographs.

a - Holotype from Stn. 28, cruise 4-06, registration number F-17

$\mathrm{b}$ - Fragment of holotype

c - Fragment of holotype with base of secondary plate

d - Fragments of specimen from Stn. 204, cruise 18-01

e - Specimen from Stn. 8655, cruise 4-09, side view

f - Specimen from Stn. 8655, cruise 4-09, top view

$\mathrm{g}$ - Specimen from Stn.t.8726, cruise 4-09, side view

$\mathrm{h}-$ Specimen from Stn. 8726, cruise 4-09, margin of the test showing internal compartments.

Scale bars: a, e, g- $10 \mathrm{~mm}, \mathrm{~b}-5 \mathrm{~mm}, \mathrm{c}-1,5 \mathrm{~mm}$

596 Fig. 3. Psammina multiloculata sp.nov., specimen from Stn.204, cruise 18-01; scanning 597 electron micrographs.

$598 \quad a-$ Surface of the test

599 b - Detail of surface showing xenophyae (fragments of sponge spicules and radiolarians)

$600 \mathrm{c}-$ Test interior showing compartments

$601 d$-Oval stercomare mass within compartment

602 e - Stercomare strings (left) and granellare branch (right) 
f - Granellare branch

$\mathrm{g}$ - Detail of granellare branch containing numerous granellae (barite crystals)

$\mathrm{h}$ - Single granella

Scale bars: a, c $-1000 \mu \mathrm{m}, \mathrm{b}, \mathrm{d}, \mathrm{f}-100 \mu \mathrm{m}, \mathrm{e}-30 \mu \mathrm{m}, \mathrm{g}-10 \mu \mathrm{m}, \mathrm{h}-3 \mu \mathrm{m}$

Fig. 4. Psammina limbata sp.nov., Stn. 25, cruise 4-06, 4724 m, holotype, registration number F-18.

, a - Intact test attached to host nodule.

$\mathrm{b}$ - Test detatched from nodule showing concentric zonation.

c - Surface of the test showing xenophyae.

d - Outer layer of test underlain by internal xenophyae (mainly sponge spicules), stercomare and granellare

e - Stercomare mass

f - Single granella (barite crystal)

$\mathrm{g}$ - Small ridge on underside of outer test layer

$\mathrm{h}$ - Weakly-developed zonation on underside of outer test layer inside test

i - Margin of test consisting of sponge spicules

Scale bar: a, b- $1 \mathrm{~cm}, \mathrm{~g}-1 \mathrm{~mm}, \mathrm{~d}, \mathrm{i}-200 \mu \mathrm{m}, \mathrm{c}, \mathrm{h}-100 \mu \mathrm{m}, \mathrm{e}-20 \mu \mathrm{m}, \mathrm{f}-3 \mu \mathrm{m}$

Fig. 5. Spiculammina delicata, variation in test morphology of specimens attached to nodules (cruise 4-06).

a - Stn. 118

b - Stn. 166

c - Stn. 159

d - Stn. 43

e - Stn. 119

f - Stn. 164

632 Fig. 6. Test structure of Spiculammina delicata, from Stn. 25, cruise 4-06; scanning electron 633 micrographs.

634 a - Surface of the test

$635 \quad b$ - Detail of test wall showing xenophyae (sponge spicules)

$636 \mathrm{c}$ - Test interior containing stercomare, granellare and xenophyae 
Fig. 7. Stannophyllum radiolarium; a,b, light micrographs; c - f, scanning electron micrographs.

a- Specimen from Stn. 8639; dimensions 22x15 mm

b- Specimen from Stn.31 attached to host nodule; dimensions $32 \times 25 \mathrm{~mm}$

c- Surface of the test showing xenophyae (radiolarians).

d- Linellae and stercomare mass

e- Detail of linellae

f- Granellare branch with granellae

Scale bar: c,d-100 $\mu \mathrm{m}$; e, f, $10 \mu \mathrm{m}$

Fig. 8. Stannophyllum sp. from Stn 197, cruise 18-01; a,b, light micrographs; c - i, scanning electron micrographs.

a- Specimen as originally found in box core, attached to a nodule

b- Damaged fragment in Petri dish

c- Test surface showing xenophyae (radiolarians)

d, e- Test interior with granellare branches and internal xenophyae

f- Single granella (barite crystal)e

g- Mass of granellae within granellare branch

h- Stercomare

i- layer of linellae

Scale bar: b- 1 cm; d- $300 \mu \mathrm{m}$; c, e- $100 \mu \mathrm{m}$; i- $30 \mu \mathrm{m}$; h- $10 \mu \mathrm{m}$; f, g- $3 \mu \mathrm{m}$ 
670

1671

2672

$\begin{array}{ll}3 & 673\end{array}$

5674

6675

7676

$\begin{array}{ll}8 & 677\end{array}$

10678

11

12

13

14

15

16

17

18

19

20

21

22

23

24

25

26

27

28

29

30

31

32

33

34

35

36

37

38

39

40

41

42

43

44

45

46

47

48

49

50

51

52

53

54

55

56

57

58

59

60

61

62

63

64

65 

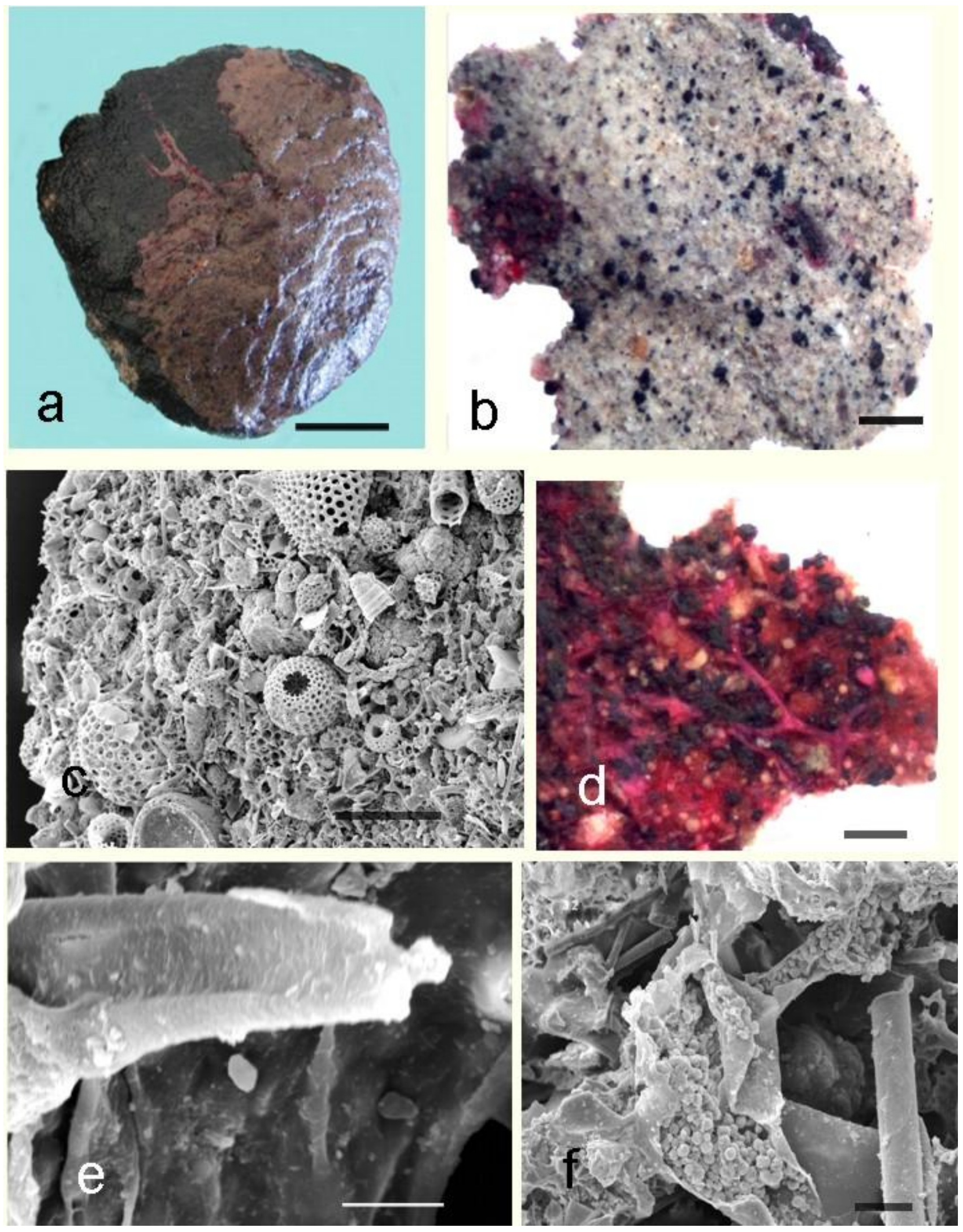

Fig.1 

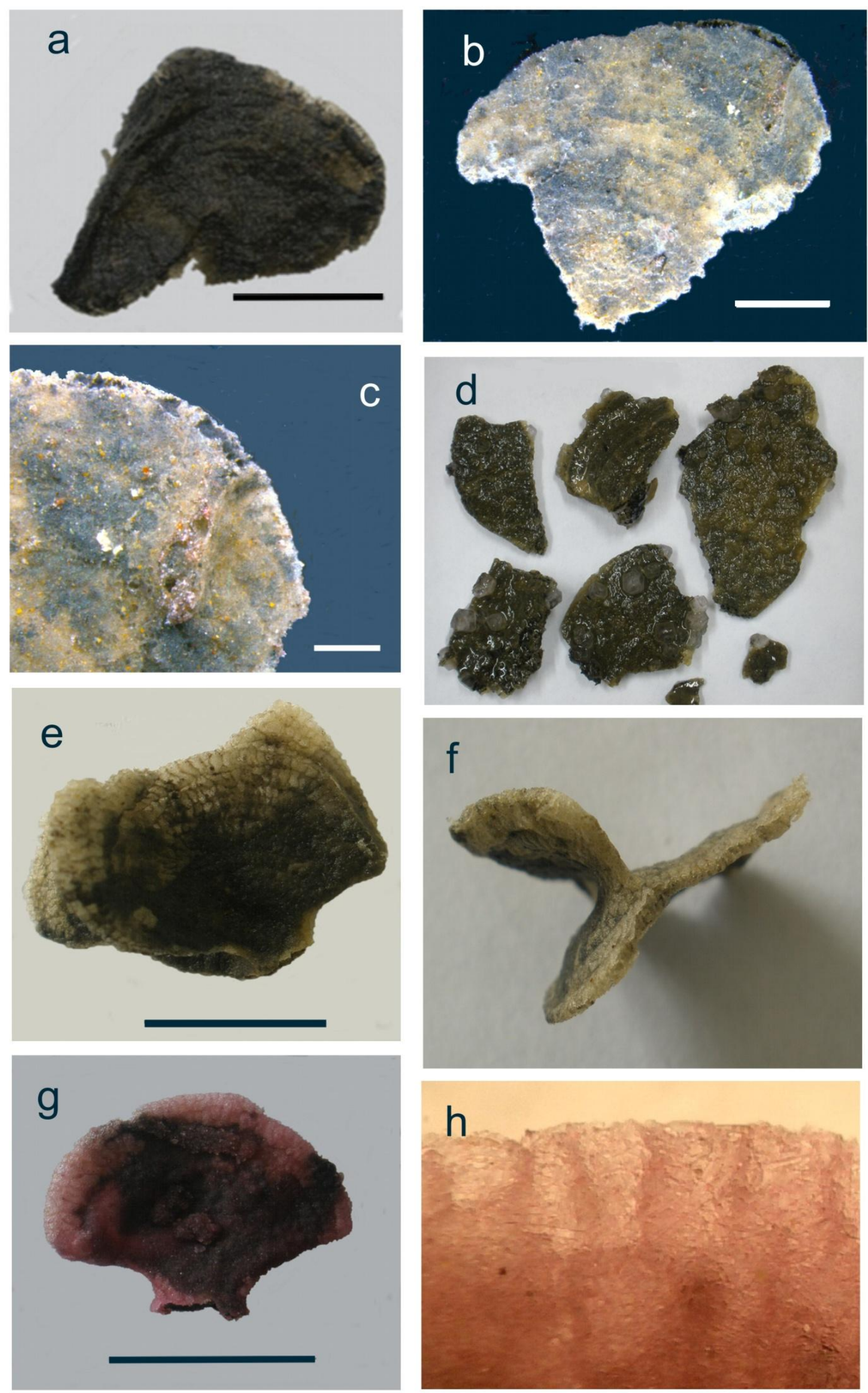

Fig.2 


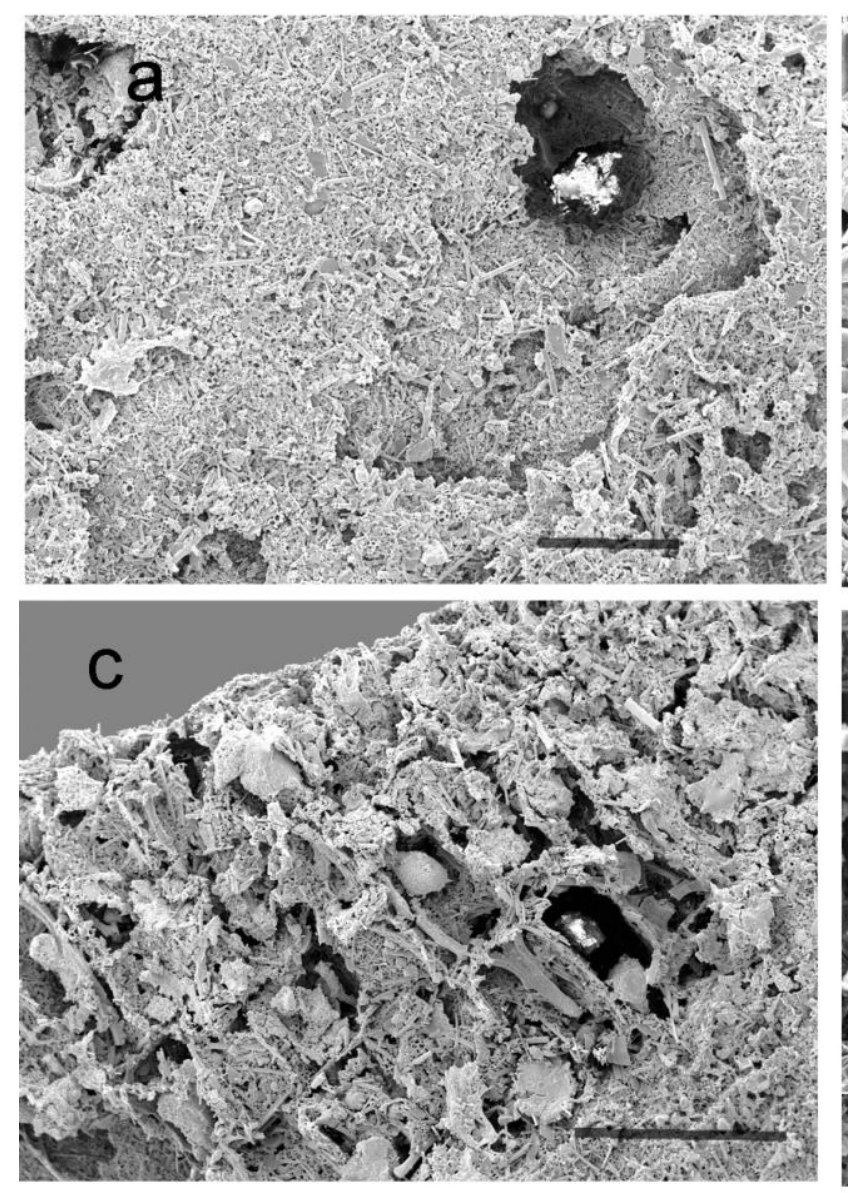

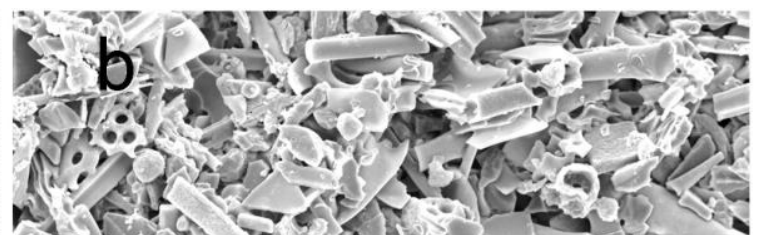

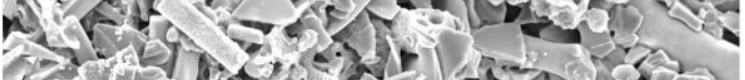

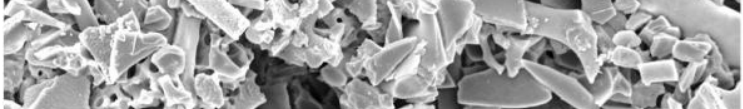
in, s- 12.5

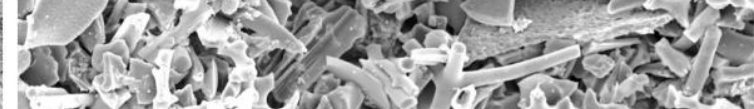
(2)

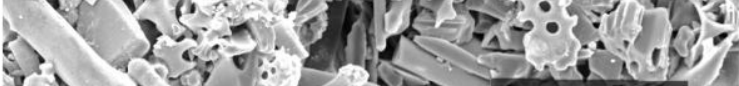

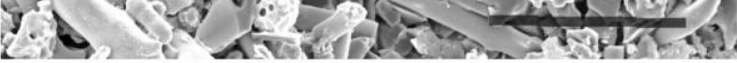
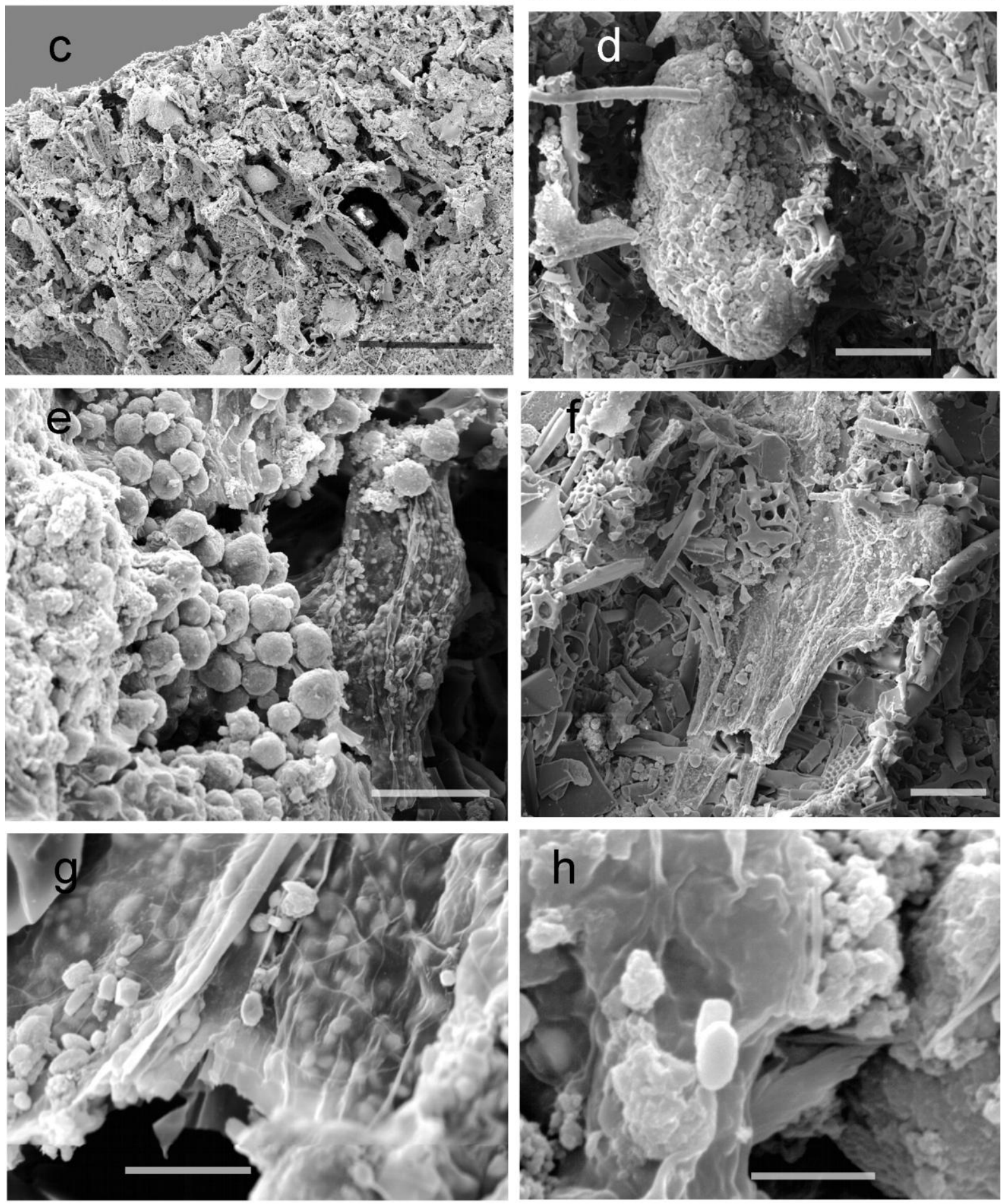

Fig.3 

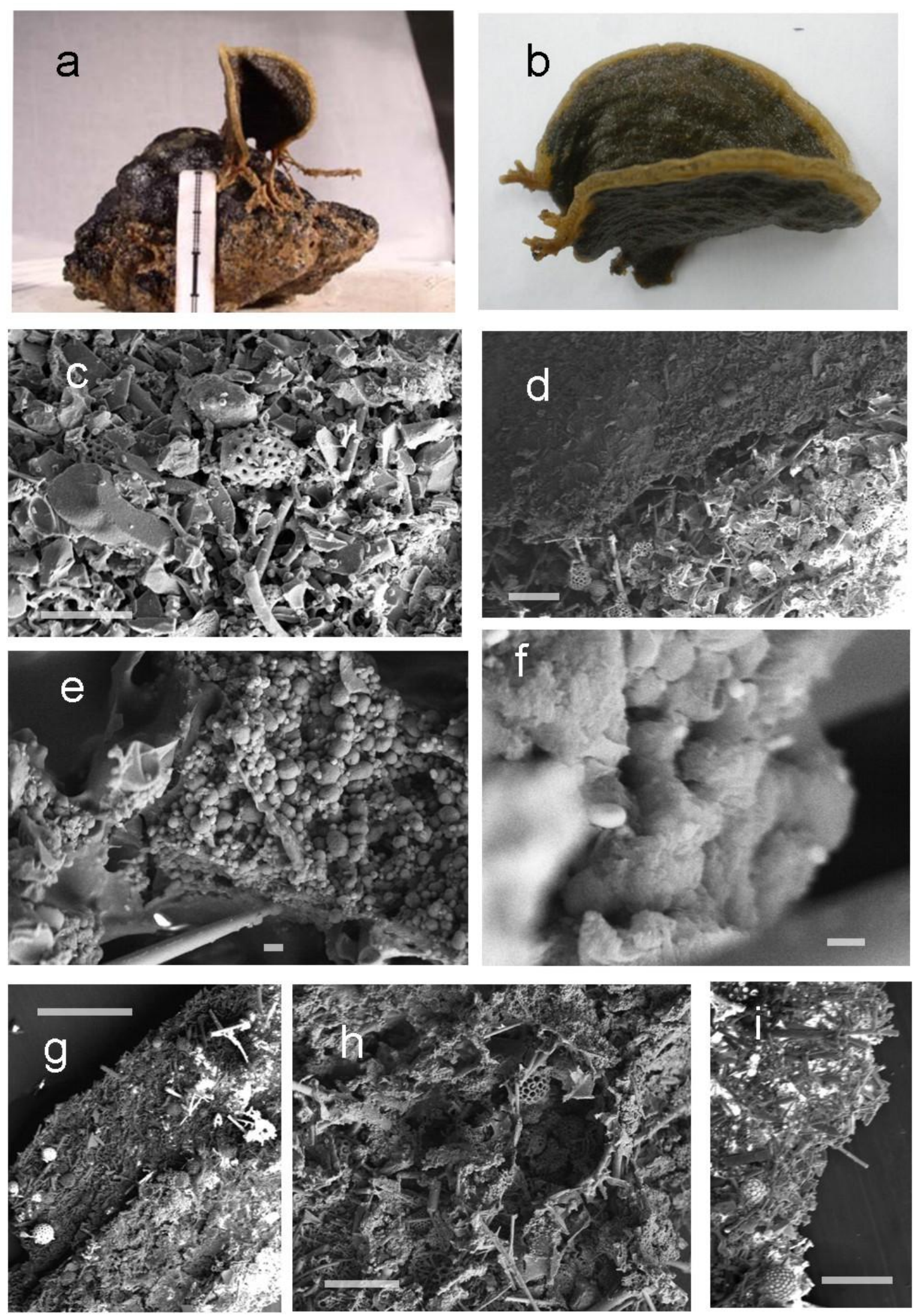

Fig.4 


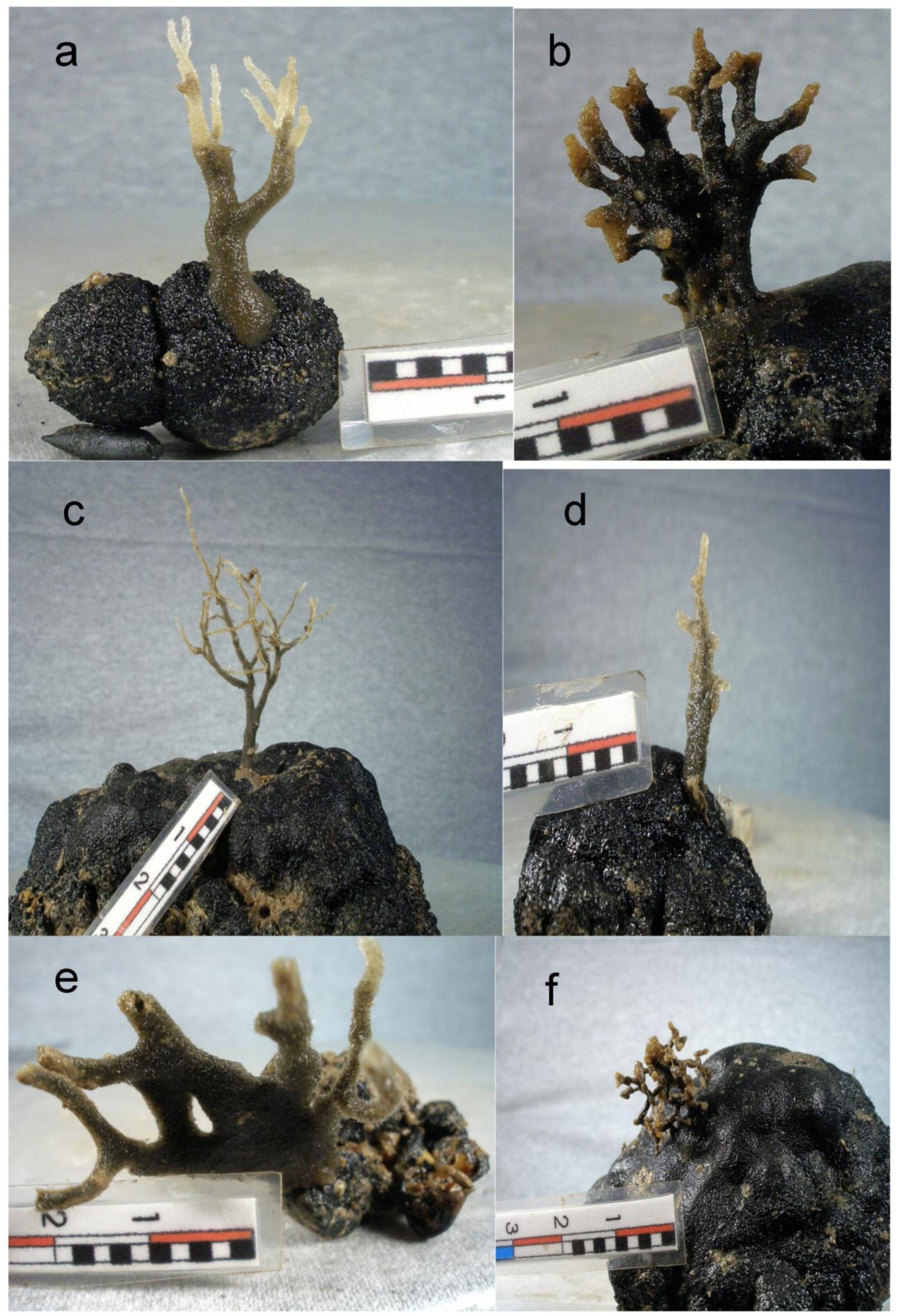

Fig.5 

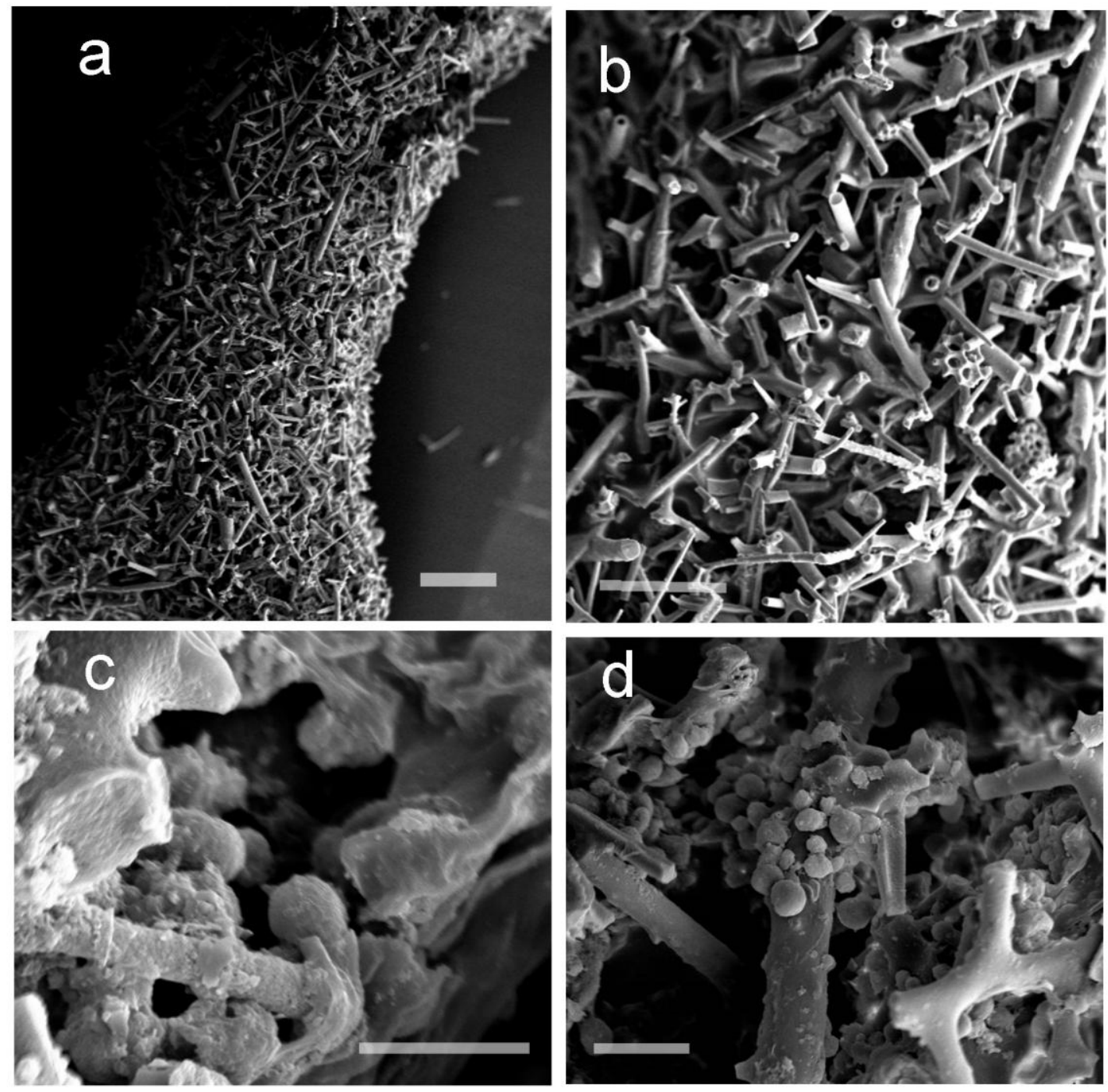

Fig.6 

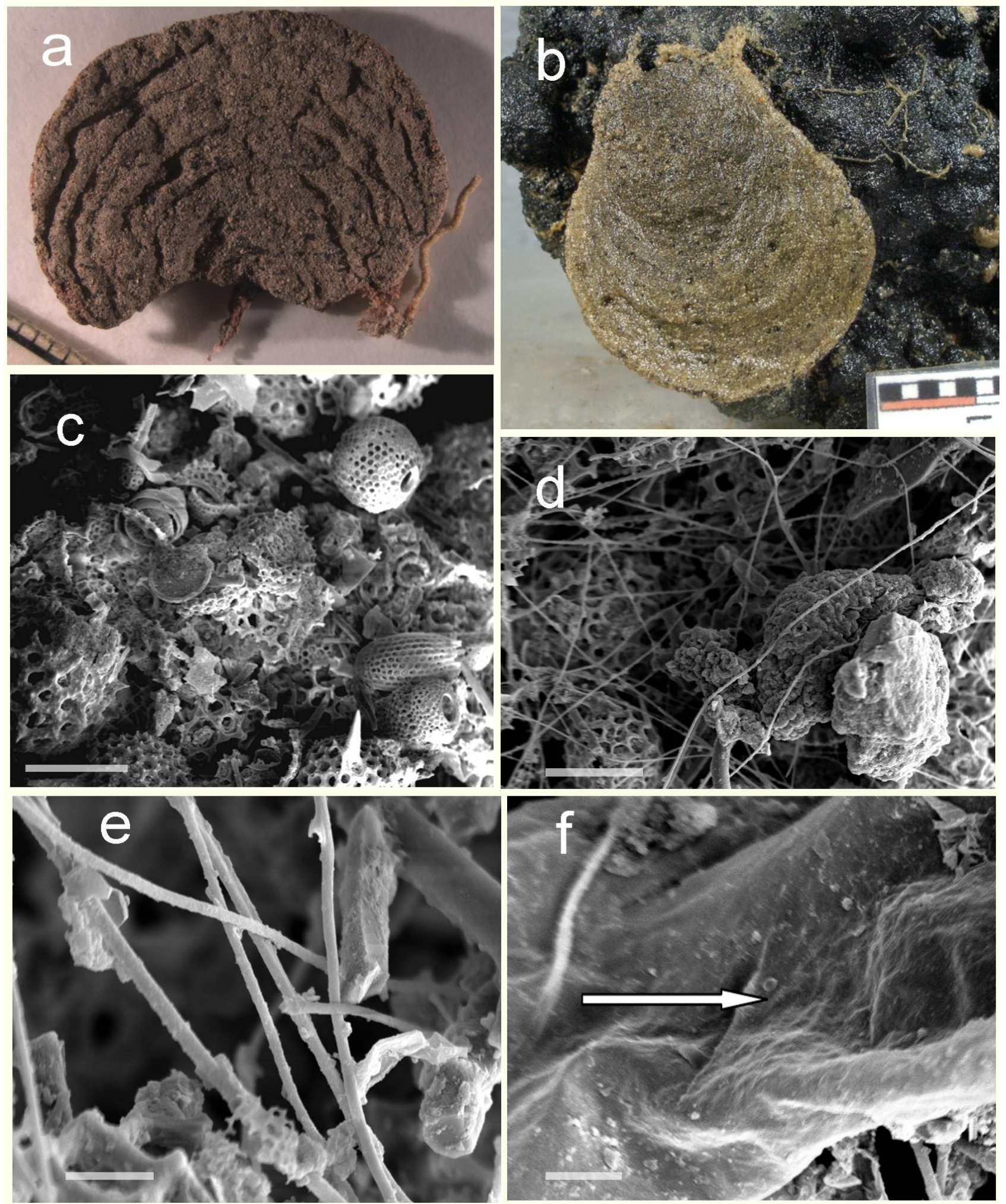

Fig.7 

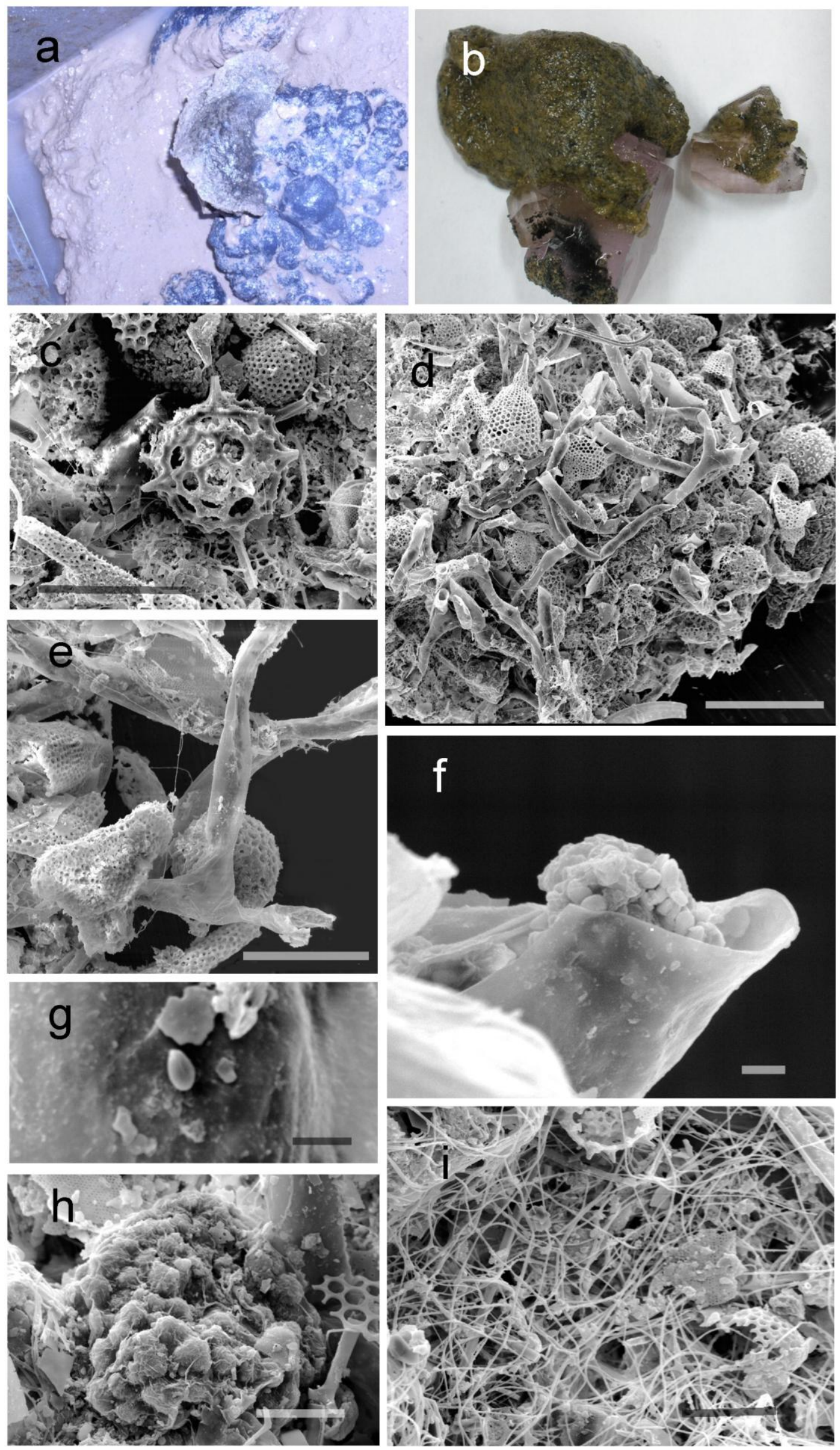

Fig.8 
Table 1. List of stations from cruises of R/V Yuzhmorgeologiya with xenophyophores from the Clarion-Clipperton nodule field.

\begin{tabular}{|c|c|c|c|c|c|}
\hline $\begin{array}{l}\text { Station } \\
\mathrm{N}\end{array}$ & Cruise & Year & $\begin{array}{l}\text { Coordinates } \\
\mathrm{N},\end{array}$ & $\begin{array}{l}\text { Depth } \\
\mathrm{m}\end{array}$ & Species \\
\hline 25 & $4-06$ & 2006 & $13.28^{0} 134.45^{0}$ & 4724 & $\begin{array}{l}\text { Psammina limbata, } \\
\text { Spiculammina delicata }\end{array}$ \\
\hline 28 & $4-06$ & 2006 & $13.29^{0} \quad 13.41^{0}$ & 4843 & Psamina multiloculata \\
\hline 31 & $4-06$ & 2006 & $13.31^{0} \quad 134.41^{0}$ & 4785 & Stannophyllum radiolarium \\
\hline 34 & $4-06$ & 2006 & $13.31^{0} \quad 134.32^{0}$ & 4742 & Spiculammina delicata \\
\hline 39 & $4-06$ & 2006 & $13.26^{0} \quad 134.47^{0}$ & 4716 & Spiculammina delicata \\
\hline 43 & $4-06$ & 2006 & $13.28^{0} \quad 134.42^{0}$ & 4753 & Spiculammina delicata \\
\hline 49 & $4-06$ & 2006 & $13.29^{0} \quad 134.34^{0}$ & 4755 & Spiculammina delicata \\
\hline 52 & $4-06$ & 2006 & $13.24^{0} 134.53^{0}$ & 4787 & Spiculammina delicata \\
\hline $60-1$ & $4-06$ & 2006 & $13.26^{0} \quad 134.42^{0}$ & 4777 & Semipsammina licheniformis \\
\hline 85 & $4-06$ & 2006 & $13.27^{0} 134.32^{0}$ & 4820 & Spiculammina delicata \\
\hline 94 & $4-06$ & 2006 & $13.23^{0} 134.44^{0}$ & 4772 & Spiculammina delicata \\
\hline 95 & $4-06$ & 2006 & $13.23^{0} 134.43^{0}$ & 4786 & Spiculammina delicata \\
\hline 118 & $4-06$ & 2006 & $13.24^{0} \quad 134.34^{0}$ & 4778 & Spiculammina delicata \\
\hline 119 & $4-06$ & 2006 & $13.24^{0} \quad 134.33^{0}$ & 4825 & Spiculammina delicata \\
\hline 122 & $4-06$ & 2006 & $13.19^{0} \quad 134.51^{0}$ & 4820 & Spiculammina delicata \\
\hline 133 & $4-06$ & 2006 & $13.22^{0} \quad 134.37^{0}$ & 4788 & Spiculammina delicata \\
\hline 150 & $4-06$ & 2006 & $13.27^{0} 134.43^{0}$ & 4778 & Spiculammina delicata \\
\hline 151 & $4-06$ & 2006 & $13.27^{0} 134.43^{0}$ & 4776 & Spiculammina delicata \\
\hline 159 & $4-06$ & 2006 & $13.26^{0} \quad 134.45^{0}$ & 4755 & Spiculammina delicata \\
\hline 164 & $4-06$ & 2006 & $13.26^{0} 134.43^{0}$ & 4769 & Spiculammina delicata \\
\hline 166 & $4-06$ & 2006 & $13.26^{0} \quad 134.42^{0}$ & 4777 & Spiculammina delicata \\
\hline 167 & $4-06$ & 2006 & $13.26^{0} \quad 134.42^{0}$ & 4789 & Spiculammina delicata \\
\hline 197 & $18-01$ & 2003 & $13.55^{0} \quad 129.02^{0}$ & 4845 & Stannophyllim sp. \\
\hline 204 & $18-01$ & 2003 & $13.90^{0} \quad 129.14^{0}$ & 4896 & Psammina multiloculata \\
\hline 8639 & $4-08$ & 2009 & $12.77^{0} 133.41^{0}$ & 4750 & Stannophyllum radiolarium \\
\hline 8655 & $4-09$ & 2010 & $12.72^{0} \quad 133.59^{0}$ & 4841 & Psammina multiloculata \\
\hline 8726 & $4-09$ & 2010 & $13.54^{0} \quad 133.42^{0}$ & 4936 & Psammina multiloculata \\
\hline
\end{tabular}

